\title{
Analysis of Internal Control in the Distribution of Agricultural Business Credit
}

\author{
Sulfiani \\ Management Department, Faculty of Economy and Social, State University of Makasar, \\ Indonesia \\ Received: August 2, 2020 \\ Received in Revised: August 11, 2020 \\ Accepted: August 13, 2020
}

\begin{abstract}
Library research, namely the authors collect data related to the theory of financing or lending to economically weak entrepreneurs. Field research, namely field research activities, in which the author looks for data that is the object of research, to obtain data the author conducts local observations and direct interviews with the leadership. Observation techniques were carried out by conducting direct observations in the process of distributing credit to economically weak entrepreneurs. Based on the description above, so the authors chose the title "Analysis of Internal Control in Distribution of Farmers Business Credit".
\end{abstract}

Keywords: Bank, Agricultural Business, Credit, Collectibility

\section{Introduction}

One of the government's efforts to improve people's lives is to empower the role of banking services. The role of banking services as a financial institution, namely collecting public funds, then as a source of business for financing the business world, which is very important in supporting and developing economic growth. Banks as a business unit in carrying out their functions develop two interrelated functions, namely: Function as executor development and commercial functions that seek to benefit from the development and continuity of their business. To carry out its functions, in particular the commercial function with operational activities in the credit sector and to provide direction and guidelines for banks in implementing these credit operations. As it is known that the development of small businesses is a complex matter and includes many factors, including economic, social cultural, political, and other factors. Therefore, small business development efforts must be carried out by all related parties in a coordinated manner and together through various comprehensive and conceptual programs. For equal distribution of business sectors, the government issued a policy in the form of agricultural business credit facilities channeled by state banks. The feasibility of lending agricultural business loans is an operational activity that greatly supports the further development of a bank. To support and ensure the smooth distribution of agricultural business credit, it is necessary to have a procedure, namely internal control as a management function that is generated automatically through a certain procedure, the procedure in question is the sequence of implementation that must be examined by someone in taking an action for achieve a specific goal.

The ultimate goal of the Bank is to strive for the survival of small entrepreneurs through sound banking businesses and achieving fair profit. This means that in the operation of a Bank (company) must make efforts in accordance with the applicable regulations. And the main objective is also to participate in building and developing the national economy, especially the improvement of the welfare of the middle to lower class society through the provision of appropriate financing. In the midst of this sluggish condition of economic activity and diverse competition, PT Bank Rakyat Indonesia as one of the agents of development that functions as an intermediary institution that distributes credit, must be able 
to offer innovative products while adhering to the principles of prudential banking. . This is done in order to avoid the risk of bad credit, especially at Soppeng. large scale credit. One of the important factors to oversee the smooth distribution of credit and to reduce the level of credit risk, needs to carry out internal supervision of the credit that has been distributed. Based on the description above, so the authors chose the title "Analysis of Internal Control in Distribution of Farmers Business Credit"

\section{Bank}

The role of banking greatly affects the economic activities of a country. Banks can be said to be the blood of a country's economy. Therefore, the progress of a bank in a country can also be used as a measure of the progress of the country concerned. The more developed a country is, the greater the role of banks in controlling the country. This means that the existence of the banking world is increasingly needed by the government and its people.

According to law no. 10 of 1998 concerning amendments to law No.7 of 1992, "Banks are business entities that collect funds from the public in the form of deposits, and channel them in the form of credit in order to improve the standard of living of the people at large". Melayu S.P Hasibuan (2001: 1) explains that "a bank is a financial institution, meaning a bank is a business entity whose wealth is primarily in the form of financial assets (Financial Asset) and is profit-motivated and also social, which is not only for profit." According to Lukman Dendawijaya (2001: 25), a bank is a business entity whose main task is as a financial intermediary institution that distributes funds from parties that have excess funds to parties who need funds or lack of funds (Deficit Unit) at a specified time.

From some of the definitions of a bank that have been stated above, it can be concluded that basically a bank is an institution that trades money whose role and function in society as a public fund-collecting institution as a credit institution and as an institution that launches trade transactions and money payments, and to launch all activities public finance. To find out more about the role that a bank can play, it can be seen from the definition of the bank. A bank can be defined as a financial institution whose main business is to collect funds and channel these funds back to the public in the form of credit and provide services in payment traffic and money circulation.

\section{Credit and types of credit}

The definition of credit itself has different dimensions, starting from the meaning of the word credit which comes from the Greek credere which means trust or in Latin creditum which means belief in truth. The definition of credit according to law No. 10 of 1998 "Credit is the provision of money or an equivalent claim, based on a loan agreement or agreement between the bank and another party which requires the borrower to repay the debt after a certain period of time with interest in return. or profit sharing. According to Teguh Pudjo Muljono (2001: 56) Credit is the ability to carry out a purchase or make a loan with a promise that the payment will be deferred for an agreed period of time. Muhdarsyah Sinungan (2001: 234) Credit is a performance award by one party to another party in that the achievement will be returned again at a certain time in the future accompanied by a counter-achievement in the form of interest. Some of the opinions mentioned above, it is clear that credit in an economic sense is a delay in payment of current achievements, whether in the form of goods, money or services. It can also be seen that the element of trust and time is the most important element in a credit.

\section{Collectibility}


What is meant by credit collectibility is a condition where the payment of loan principal and interest by the customer is visible in bank administration. Based on the collectibility, loans can be classified into 5 (five) types, namely, Current, namely loans and principal and interest payments are in accordance with the loan in question, including changes approved by the bank. Substandard, namely a loan whose principal payment is not made with the loan agreement concerned, for example: Loans that are past due are not extended and will not exceed three months. There are arrears in principal payments after three months, and interest arrears that are past one month and based on the bank's assessment, the debtor can pay off his debt and all of the interest. Especially for access loans whose term has passed and has not been extended but has not exceeded three months and based on the bank's assessment, the debtor can still pay off his debt and all interest.

Doubtful, is a loan that is past due and is past three months and based on the bank's assessment, the debtor cannot pay back all the debt and interest, only expected to be repaid now. Less than $50 \%$ of the debit balance is a loan without a credit agreement and without acceptance, which is based on the bank's assessment, it is expected that at least $50 \%$ of the debit balance will be paid. Loss, namely loans that cannot be categorized into the three types mentioned above, and according to the bank's assessment, it can only be expected that repayment is less than $50 \%$ of the debit balance. Credit under supervision, namely before the purchase of credit, credit assessment or analysis is first conducted.

\section{Supervision}

According to Rahmat Firdaus (2004: 190) states that supervision is an activity to find out whether work is carried out in accordance with the plan or not, with the intention of being able to prevent irregularities and if deviations have occurred, corrective action can be taken immediately. According to Sondang P. Siagian (1998: 258) Supervision is the whole effort of observing the implementation of operational activities to ensure that these various activities are in accordance with predetermined plans. Supervision is closely related to planning. The supervision strategy needs to be arranged, in order to achieve the desired goals or targets, no manager can carry out supervision if they have not made or prepared a good plan. Good supervision makes it possible for a manager to experience that all organizational activities can be carried out properly if they are not supported by a good plan. The description above illustrates that what needs to be considered in carrying out the supervisory function is the activity of examining whether the wheels of the organization can run or can be achieved according to a predetermined plan.

Supervision can be carried out according to the orders and principles set. When a lot of mistakes or mistakes are found under supervision, it is corrected and tries to prevent their recurrence, this means that the orientation of the supervision includes objects and people. Systems and techniques in supervision must describe the adjustment of the plan, as a guide that determines the direction that is always associated with the position or position of a person in charge of the company, this means that the scope of supervision must be differentiated according to the pattern and structure of the company organization, which is to explain the role of someone in the company, which must be responsible.

\section{Internal control}

According to Teguh Pudjo Mujono (1999: 28) states that internal control includes the structure of the organization and all the methods and regulations that have been established or companies to safeguard and secure their property, check the accuracy and correctness of administrative data, promote work efficiency and encourage compliance. policies that have been set by top management. The development of the business world and the increasingly 
complex problems faced by experts in making improvements and broadening the insights of internal control still need to be added regarding the aspects of protecting company property in the supervision system. So the meaning of intren and checking supervision includes checking and controlling the intren. Internal supervision is increasingly becoming known as an important supervisory tool and attracts the attention of entrepreneurs and accountants where developments like this invite experts working in the fields of accounting and management to make improvements in the formulation of roles and the meaning of internal control. According to Indra Bastian (2003: 203), internal control includes organizational structure, methods and measures that are coordinated to maintain organizational wealth, check the accuracy and reliability of accounting data, promote efficiency and comply with leadership policies. According to Ernie Tisnawati Sule (2005: 328) states that internal supervision is supervision that is carried out independently by each worker regarding the duties assigned to him.

The definition of internal control in a broad sense includes matters that are directly related to the functions of the Ministry of Accounting and Finance, such as oversight of the budget system, standard costs, periodic operational reports, statistical analysis, training programs to help employees able to understand and carry out their duties and responsibilities, the presence of an internal examiner staff who gives assurance to management regarding the established procedures, whether they are sufficient or have been carried out properly. Actually, internal control also has a role in other fields which include research activities, time and motion which are technical fields as well as the use of quality through an inspection system which is basically a product function.

\section{Effectiveness}

According to Hani Handoko (1999: 7) states that effectiveness is the ability to choose the right goal or the right equipment to achieve the goals that have been set. According to Mulyadi (2001: 147) states that effectiveness is the implementation of plans that require control in order to achieve predetermined goals. So effectiveness is the best activity between efforts and results, between work and results achieved to achieve goals. The result means that a job can be called effective if with certain efforts it can give maximum results regarding the quality or number of units of output or in other words the quality and quantity is guaranteed. Effort means that a job can be said to be effective if a certain result is achieved on a goal. It is clear that if the goals or objectives have been achieved in accordance with what was planned beforehand, it is effective, so if the goals or objectives are not achieved and are not completed at the specified time, then the work is not effective.Farmers Business Credit

The purpose of issuing agricultural business credit is to assist farmers in increasing food production, especially rice and secondary crops, and the income and welfare of the farmers concerned, in addition to mobilizing public funds in an effort to support the formation of development funds from the community, as well as creating equal opportunities to obtain service facilities. banking at the rural level. According to Faisal Afif (1999: 93) states that agricultural business credit is a working capital credit intended for farmers to spend on their farming in the context of intensifying rice / secondary crops. According to MG. Sulistyawardhani (2000: 47) agricultural business credit is a credit to cover the costs of cultivating land, purchasing rice seeds, purchasing agricultural equipment, and renting or purchasing rice fields and livestock and so on related to farming.

\section{Operational}

To provide a clear picture and facilitate the conduct of research, it is necessary to provide a definition of the variables under study, as follows. Effectiveness is the execution of plans that 
require control in order to achieve predetermined goals. Internal Control includes the organizational structure and all the methods and regulations that have been established by the company to safeguard or secure its assets, check the accuracy and correctness and administration, promote work efficiency and encourage compliance with policies set by management. efforts to observe the implementation of operational activities in order to ensure that these various activities are in accordance with predetermined plans. Wisdom is a guideline that guides and directs activities and efforts to make decisions about what is carried out by the organization. Credit is the provision of money or an equivalent claim, based on a loan agreement or agreement between the Bank and another party which requires the borrower to repay the debt after a certain period of time by giving interest in return or sharing the profits.

\section{Discussion}

At the end of the XIX century, precisely on December 16, 1895 R. Wira Admaja and his friends founded the "Depurwokwrtosce Hulp-en Spear Bank Inlandesche Hoofden" (Bank of assistance and savings for ancient priyayi), with an authentic certificate made by E. Siebrug later founded "Depurwokwrtosce Hulp Spaer en Landbowchrediet Bank" as a continuation of Depurwokwrtosce Hulp-en Spear Bank Inlandesche Hoofden.

In 1898 with the assistance of the Dutch East Indies government they established Volkbankena or also known as Bank Rakyat Indonesia, whose working area covered the entire administrative district or afdeling which was also known as afdelingbanken. In the twentieth century Volbanken experienced difficulties so that the Dutch East Indies government intervened in people's credit, and since 1904, founded Dients den volkecredietwessen (people's credit service) which was tasked with helping volkbanken by providing additional capital, guidance, guidance and supervision so that people's credit began in 1904 to become regeriezrog (government duties). In 1912 the Dutch East Indies government established an institution that was incorporated under the name central cash which functioned as the Volkbanken Central Bank which generally included village banks. As a result of the world recession in 1912-1932 Volkbanken was not able to do well in overcoming its difficulties. In 1934 with a stable 1932-1982 Algemene Volkbanken Bank (AVB) which was incorporated in Europe was established with the first working capital derived from the liquidity of Central Cash plus the net worth of the volkbanken. thus, Algemenevolkscrediet bank is a continuation of Cenaral Cash which is the integrity of the bank's volume.

During the Japanese occupation, AVB on the island of Java was renamed to Ayoomin Ginko (Bank Negara Indonesia) based on Law No. 39 in 1942. After the proclamation of Indonesian independence on August 17, 1945 with government regulation no. 1 in 1935, the government established the Bank Rakyat Indonesia which was named Algemene Volkcrediet Bank (AVB) which later became Syoomin GINKO. while the NICA (Nederlands Indies Cipil Administration) in Jakarta re-established the Algemene Volkcrediet Bank large office.

In 1948 after the capital of the Republic of Indonesia, namely Yogyakarta, was occupied by the Dutch, the headquarters of Bank Rakyat Indonesia were abolished by the Dutch (NICA) and then its directors were imprisoned for not cooperating with Algemene Volkcrediet Bank. Since then the activities of Bank Rakyat Indonesia have been temporarily suspended. Partly as a result of the Roem-Royen agreement, the BRI head office came back to life, but its working area only covered areas returned to the Republic of Indonesia in 1945, namely the Rendville area, while in another area called Algemene Volkcrediet Bank it was changed to BARIS (Bank Rakyat Indonesia Serikat) . 
The development of Indonesia's political history turned out to have a very big influence on the development of BRI with the Decree of the Minister of Prosperity of the RIS dated March 16, 1959, the board of directors of the People's Republic of Indonesia moved from Jogyakarta to Jakarta to become the board of directors of BARIS, but the decree received protests from the federation, because the office The size of BARIS was not yet a reality, so the Minister of Prosperity of RIS corrected it by naming the BARIS directors as AVB / BRI directors. Even though on August 17, 1950, the RIS State with the 1950 Constitution was made the Republic of Indonesia as a unitary state, Volkscrediet Bank was only dissolved on 19 August 1951 based on Law No. 12 of 1951. In addition to government regulation no. 25 of 1951 confirmed that 20 April 1951 was made as an intermediary bank.

With the issuance of a Presidential Decree to return to the 1945 Constitution, the government regulation in lieu of Law (PERPU) No. 14 of 1960 on 28 October 1960, State Gazette 128 of 1960 formed the Cooperative, Farmers and Fishermen Bank, abbreviated as BKTN, in which banks should be merged and integrated respectively.

\section{Result}

Banks in accordance with the results of the author's research have experienced an increase in both the amount of credit channeled and the number of members experiencing the same thing, because the farming community utilizing the credit they have taken really feels the impact of KUT assistance in the regions, so that the farming community as partners with the Bank is mainly towards increasing income ( income).

Based on the number of loans and the number of customers each year, there is an increase in income for those who use the KUT facility through the Bank, namely from 2002 the number of members has increased until 2006, so that BRI sometimes feels overwhelmed to serve customers during the planting season, it's just that the requirements to obtain credit must be met. Farmers' income can increase due to cooperation with Bank, so that the day the customer increases, the proposed hypothesis can be accepted or proven. For more details, PT Bank in increasing the number of customers and income from Farmers Business Credit from 2002 to 2006

\section{Methods}

In this study, the following data collection methods were used. In the data collection process, the authors conducted case studies and data collection through field research and library research, as follows. Library research, namely the authors collect data related to the theory of financing or lending to economically weak entrepreneurs. Field research, namely field research activities, in which the author looks for data that is the object of research, to obtain data the author conducts local observations and direct interviews with the leadership and several employees of PT. Bank Rakyat Indonesia Tbk Soppeng Branch and collect data in the form of reports that are presented and gather the necessary information

For comparison of this, the authors conducted observations. Observation techniques were carried out by conducting direct observations in the process of distributing credit to economically weak entrepreneurs. The writing of this thesis was obtained from PT Bank Rakyat Indonesia Tbk Soppeng Branch. The types of data used in the study are as follows. Qualitative Data, namely data obtained in the form of information both oral and written about internal control policies. Quantitative data, namely data obtained from banks in the form of the amount of agricultural business loans. The data sources needed in this study are as follows. Primary data, namely data obtained directly from PT Bank Rakyat Indonesia, Soppen Branch, includes data obtained through interviews with bank leaders and employees as well as data on internal control policies. Secondary data is other data obtained in 
connection with the writing of this thesis, namely in the form of a written report made periodically, such as the amount of agricultural business credit disbursement.

\section{Conclusion}

Based on the description of the previous chapter, the authors draw some conclusions that need to be stated as follows. Distribution of Farmers Business Credit to Bank for 5 five years, from 2002 to 2006 has increased, in 2002 amounting to Rp. 290,000,000, in 2003 amounting to Rp. 300,000,000, for the year 2004 amounting to Rp. 350,000,000 while for the year 2005 amounting to Rp. 380,000,000 and most recently for 2006 amounting to Rp. 400,000,000 credit distribution has increased every year. The development of small business credit withdrawals, because the procedures and distribution are quite effective and efficient, so that people need to be able to complete according to the requirements to obtain a, then this research hypothesis can be accepted (proven). banh in accordance with the distribution of credit both the amount of credit and the percentage also increased, because the main function of the bank is receiving savings, in addition to channeling it back to the needy. The distribution of agricultural business credit for the period 2002 to 2006 is in accordance with the results of research which has increased every year, so that the province in every region / city exists to support the community. The bank as the mobilization of funds from third parties, the bank anticipates the demand for credit, because the credit that has been distorted by third parties will be channeled back, because how can the parties give sympathy to the public to increase their balance in the bank.

\section{References}

Afif, Faisal. 1997, Strategy and Operasional Bank, PT. Eresco, Jakarta.

Bastian, Indra, 2003, Public Sector Accounting System, Salemba Empat, Jakarta.

Denda Wijaya, Lukman. 2001. Banking Managemet, Ghalia Indonesia, Jakarta.

Firdaus, Rachmat dan Ariyanti, Maya. 2004, general baning management, ALFABETA, Bandung.

Handoko, Hani.T. 1999, Management, edisi kedua, BPFE, Yogyakarta.

Hasibuan, Malayu, S, P. 2001. Basic of bank managemment, Bumi Aksara, Jakarta.

Kuncoro, Mudrajad dan Suharjono, 2002. Bankig Mnagement, Edisi Pertama, BPFE Yogyakarta, Yogyakarta.

Pudjo Muljono, Teguh. 1999, Bank Auditing Bank Internal Examination Instructions, Djambatan, Jakarta.

Siagian, Sondang. 1998, Manaj Stratejik, Bumi Aksara, Jakarta.

Sulistyawardhani, MG. 2000, society credit, Yayasan Kalika Budaya,, Yogyakarta.

Tisnawati Sule, Ernie. 2005, Introduction to Management, Kencana, Jakarta.

Mulyadi,2001, Accounting management, Salemba Empat, Yogyakarta. 